\title{
Mode Shifts in Conversations with People with Dementia can Cause Confusion
}

ISSN: 2578-0093

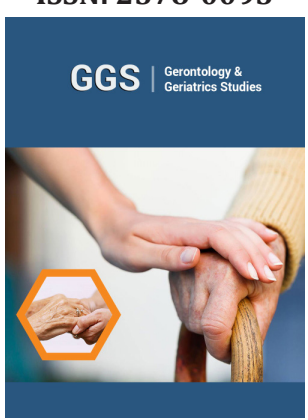

*Corresponding author: Margaret Maclagan, School of Psychology, Speech and Hearing, University of Canterbury, New Zealand,

Email: margaret.maclagan@canterbury. ac.nz

Submission: 地 August 10, 2019

Published: 海August 21, 2019

Volume 4 - Issue 5

How to cite this article: Margaret Maclagan, Boyd Davis. Mode Shifts in Conversations with People with Dementia can Cause Confusion. Gerontol \& Geriatric stud.4(5). GGS.000600.2019.

DOI: 10.31031/GGS.2019.04.000600

Copyright@ Margaret Maclagan, This article is distributed under the terms of the Creative Commons Attribution 4.0 International License, which permits unrestricted use and redistribution provided that the original author and source are credited.

\author{
Margaret Maclagan ${ }^{1 *}$ and Boyd Davis ${ }^{2}$ \\ ${ }^{1}$ School of Psychology, Speech and Hearing, University of Canterbury, New Zealand \\ ${ }^{2}$ Department of Applied Linguistics/English, UNC-Charlotte, USA
}

\section{Abstract}

We illustrate how speakers with dementia may shift the whole mode of a conversation as well as its topic or their role in it. This can confuse their unimpaired conversation partner if that partner is less aware of features of dementia discourse. Examples are drawn from three women with moderate Alzheimer's disease who were living in the south-eastern United States. These examples demonstrate the range of coherence in dementia discourse and how the mode of the conversation can shift dramatically.

Keywords: Dementia; Alzheimer's disease; Conversation; Dementia discourse

\section{Introduction}

No one is surprised when conversation with a person with dementia becomes repetitive. They expect stories to be repeated, words to be forgotten or misused or for the direction of the conversation to change abruptly. What they do not usually expect is for the whole mode of the conversation to change with no warning. We use 'mode' to refer to the listener's expectations about the conversation in this particular situation [1]. Listeners normally expect conversations to be ordered and coherent and for changes in direction to be signaled, often by a phrase like 'oh, by the way...' or even directly by something like 'to change the topic totally.... We have found a continuum of discourse in dementia from coherent to very confused. Chinaei et al. [2] :376 found that " $33 \%$ of conversations with people with middle-stage AD [Alzheimer's disease] involve a breakdown in communication." Brewer et al. [3] studied conversations with her mother-in-law. She thought they were like being on a carousel, up and down and around in circles.

\section{Discussion}

We draw here on conversations with three women with dementia. 'Maureen Littlejohn' (ML). 'Lucinda Greystone' (LG) and 'Mary Tatter' (MT). They are all white and live in Memory care units of assisted living residences in the Charlotte, NC area (USA). They all talked with the second author or her graduate students. The conversations were recorded and transcribed by HIPAA-approved research assistants or the authors; they were analyzed by the authors. For this piece, we analyzed 10 conversations for each of the women. The research was approved by the ethics review panel at UNC-Charlotte, with signed consents from legal guardians and assent from the participants. We found a continuum of coherence in dementia discourse. At one end there are coherent conversations which take some of the conversation partner's needs into account and stay reasonably on track. At the other end are confused [4] or inappropriate exchanges in which the speech events are disordered, and social expectations are befuddled. At any point, the speaker with dementia may insert a short performance tale. Such tales may or may not fit the situation or the topic and may even be repeated in the same conversation [5]. The following brief extract from a conversation with Lucinda Greystone provides a straightforward example of a shift in the mode of a conversation (marked ${ }^{* *}$ ). Int=Interviewer.

Int: [laughs] I'm allergic to potatoes too!

LG: Potatoes! Now if I lost my potatoes I'd be in trouble! [noise]

$$
\text { [3 appropriate interchanges on potatoes] }
$$

Int: Yeah, I like having a nice warm baked potato in the winter, but not anymore [laughs].

LG: Oh yeah! [laughs]. **Mother would always ask us what kind of cake we wanted for 
our birthdays. And let's see, mine's in July. She'd say, she called me sister half the time anyway. She'd say "Sister, what kind of cake do you want for your birthday?" And I'd say, "well mother if it's all the same to you mother, just make me a 'lassy cake".

LG is not just changing the topic from potatoes to cake, she is also re-positioning herself as a daughter in a family: she is both in the present, looking back at her mother, and in the past, answering as the child she had been. The change in topic and position between adult and child creates an unexpected change in the conversation mode. The cake story is a performance tale that LG inserts into many conversations.

Sometimes Mary Tatter was a coherent conversationalist as in the following extract

Int: Why did your mother call you "Penny"?

MT: Because, every time I turned around, she would have a penny and she'd say, "Here's a penny for you." And, I say, "Mama, you might as well name me Penny." And, she says, "I've done that long ago." [laughs]. <oh> So, anyway, so, I save pennies.

This story, which MT tells against herself, is a performance tale and concludes with her asking her father to go to the bank and change her fifty pennies into 'fifty cents'. Two years later, after a coherent interaction about parts of the country with her student interviewer, she abruptly shifts mode and explains apologetically that she can't really remember whether or not she's been to Alabama.

MT: To the [clears throat], the gorgeous place in the universe. [apparently referring to Alabama]

Int: Uh huh. [laughing]

MT: In my estimation.

Int: Do you really like Alabama?

MT: Oh, yeah.

Int: You've been there?

MT: I think, I don't know if they drove me through there or not. Something seems to me that, uh, I have seen it, but I can't, I can't, uh, place, "I saw this, I saw that and so on, so forth."

Switching topics, role or mode is common among speakers with moderate dementia. Maureen Littlejohn switched topics or asked questions whenever she lost track of the topic or ran out of good stories. Here, she switches from fishing as a schoolgirl to positioning herself as a grownup recalling herself as a young adult, heading to her old home for Sunday dinner. The mode has changed: both participants and situation are different from the start of the exchange.

ML: [The conclusion of a coherent story about fishing] Not that I ever caught anything, but [Laughs] it looks like it was made for business. So, anyway. It was nice growing up in the country, though.

Int: Yeah. I would have loved that.

ML: It, uh, it was just a freedom, and my mother was an excellent cook and, uh, long after we grew up and basically were more or less away from home, uh

Int: Yeah [overlap].

ML: she'd get up on Sunday morning and she'd fry her chicken and make her dressing, and she'd make a cake or some cookies or pie or something. So, all of us wanted to be the first one in [laughs] after church to see what she had made.

\section{Implications}

The increased prevalence of dementia in society means a better understanding of dementia discourse is vital for the general public and for the development of caregiver coping strategies. Caregivers face the challenge of maintaining relationships with people who are physically present but not always able to take part in appropriate social or verbal exchanges. According to Wray et al. [6] :117 caregivers "must choose between expecting the PWDs to interact like anyone else and relabeling them as operating outside the bounds of normal human communication". It is nevertheless essential that caregivers and others continue to ride the 'carousel' and converse with people with dementia. Looking more closely at shifts in the mode of the conversation may be beneficial for developing additional ways to support positive conversational interaction.

\section{Conflicts of Interests}

The authors declare that there is no conflict of interest. This research received no specific grant from any funding agency in the public, commercial, or not-for-profit sectors.

\section{References}

1. Laybutt B. (2011) Mode of discourse. Available at: Https://eflfunc. wordpress.com/2011/11/22/context-of-situation-register/ (Accessed 9 Aug 2019)

2. Chinaei H, Currie LC, Danks A, Lin H, Mehta T, et al. (2017) Identifying and avoiding confusion in dialogue with people with Alzheimer's disease. Comp Ling 43(2): 377-406.

3. Brewer J (2005) Carousel conversation: Aspects of family roles and topic shift in Alzheimer's talk. In: Davis B (Ed.) Alzheimer talk, text and context. Palgrave, New York, USA, pp. 87-101.

4. Shakespeare P (1998) Aspects of confused speech. Erlbaum, Mahwah, New Jersey, USA.

5. Davis B (2011) Intentional stance and Lucinda Greystone. In: McPherron P, Ramanathan V (Eds.) Language, body and health. Mouton de Gruyter, New York, USA, pp. 75-104.

6. Wray A (2016) Mechanisms of conflict and aggression in the dementia context. J Lang Aggression and Conflict 4(1): 114-140.

For possible submissions Click below: 